\title{
On Influence of Current Variability in the Deep Black Sea upon Water Dynamics of Narrow North Caucasian Continental Shelf
}

\author{
A.G. Zatsepin ${ }^{1}$, D.N. Elkin ${ }^{1}$, A.O. Korzh ${ }^{2}$, S.B. Kuklev ${ }^{3}$, O.I. Podymov ${ }^{3}$, \\ A.G. Ostrovskii , D.M. Soloviev \\ ${ }^{1}$ P.P. Shirshov Institute of Oceanology, Russian Academy of Sciences, Moscow, \\ Russian Federation \\ e-mail: zatsepin@ocean.ru \\ ${ }^{2}$ Atlantic Branch of the P.P. Shirshov Institute of Oceanology, Russian Academy \\ of Sciences, Kaliningrad, Russian Federation \\ ${ }^{3}$ Southern Branch of the P.P. Shirshov Institute of Oceanology, Russian Academy \\ of Sciences, Gelendzhik, Russian Federation \\ ${ }^{4}$ Marine Hydrophysical Institute, Russian Academy of Sciences, Sevastopol, Russia \\ e-mail: solmit@mhi-ras.ru
}

\begin{abstract}
The paper presents the results of research of the actual problem - influence of current variability in the deep Black Sea upon water dynamics of narrow North Caucasian continental shelf. Mechanism of sub-mesoscale eddy formation on the narrow shelf under the influence of dynamics variability of the adjacent Black Sea deep part is proposed. It is based on the in situ measurement data, satellite information analysis and the results of laboratory modeling.

The diameter of these eddies, both cyclonic and anticyclonic, is comparable to the width of the shelf (6-10 km in Gelendzhik area of the Black Sea). The absolute value of their angular rotation velocity exceeds the Coriolis parameter (absolute value of the Rossbi number $\mid$ Ro $\mid>1$ ), and their radius is less than the baroclinic Rossby deformation radius on the shelf. Presumably, these eddies have a significant effect on the ecology of shelf waters, affecting their ventilation, cross-shelf and vertical exchange, as well as kinetic energy dissipation of mesoscale and large-scale currents. It is shown that when the Rim Current is pressed against the continental slope, sub-mesoscale anticyclones are mainly formed on the shelf, and when a mesoscale anticyclonic eddy, or the Black Sea Rim Current meander, is present above the continental slope, it results in a series of sub-mesoscale cyclones. Considering that the characteristic period of oscillations of the general direction of the longshore current, caused by the Rim Current meandering, is about

10 days, it can be assumed that mainly anticyclones should be observed on the shelf during one half of the period and cyclones during the other half (anticyclonic meander, or mesoscale eddy).
\end{abstract}

Keywords: North Caucasian shelf, sub-mesoscale processes, cross-shelf transport, the Black Sea.

DOI: 10.22449/1573-160X-2016-3-14-22

(C) 2016, A.G. Zatsepin, D.N. Elkin, A.O. Korzh, S.B. Kuklev, O.I. Podymov, A.G. Ostrovskii, D.M. Soloviev

(C) 2016, Physical Oceanography

Introduction. On the basis [1 - 9] of in situ measurements, numerical and laboratory modeling and satellite altimetry data, the basin dynamics of the Black Sea deep part, with the Rim current as its main feature [10,11], is shown to be primarily defined by the Ekman (wind) pumping $W_{E}=\operatorname{rot}_{z} \tau / \rho f$, where $\tau$ is wind stress on the sea surface, $\rho$ is water density, $f$ is Coriolis parameter. It has a strongly marked annual variation. Both for the sea as a whole and for its north-eastern part $W_{E}$ reaches its maximum positive values in winter, and the minimum ones - in spring and summer. Consequently, the Black Sea cyclonic circulation is intense in winter and weak in summer. In autumn and winter the Rim Current is represented by the jet stream, pressed against the continental slope. In spring and summer it meanders strongly and sometimes breaks up into vortex structures [8, 9, 12, 13]. The phase shift between the variation of Ekman pumping velocity and the following reaction of the Rim Current is from 15 to 30 days [6, 14]. So, the intraseasonal variations in the dynamics of deep-sea part are possible, due to the changes in large-scale wind stress vorticity over the Black Sea region.

Along with the forced variability mode, the Rim Current has one of its own, manifested even during the periods of intense wind pump. This mode is related to the current's baroclinic-barotropic instability and is expressed in the meandering of the Rim Current [11]. As a result, the flow of the jet stream core either comes 
closer to the coast or goes away. When the jet approaches the coast, the longshore current velocity usually increases. When the jet is distant from the coast, its velocity decreases and even changes the sign. A typical period of the longshore current velocity variability, caused by the Rim Current meandering, is 10 days [15 $-20]$.

Results of observations. The aforementioned information is clearly confirmed by the measurement data of the Aqualog autonomous profiler on a moored buoy station [21], located at $270 \mathrm{~m}$ depth in the Gelendzhik subsatellite study site [14]. The profiler scans the water column, moving up and down the stretched rope and performing four sampling cycles a day. Vertical distributions of temperature, salinity, density and horizontal components of water flow velocity are measured simultaneously. Fig. 1 shows the time series of vertical distributions of the longshore current velocity and potential density (sigma theta) in the upper 200 m water layer during the period of November 5 - December 27, 2012, according to the Aqualog data.

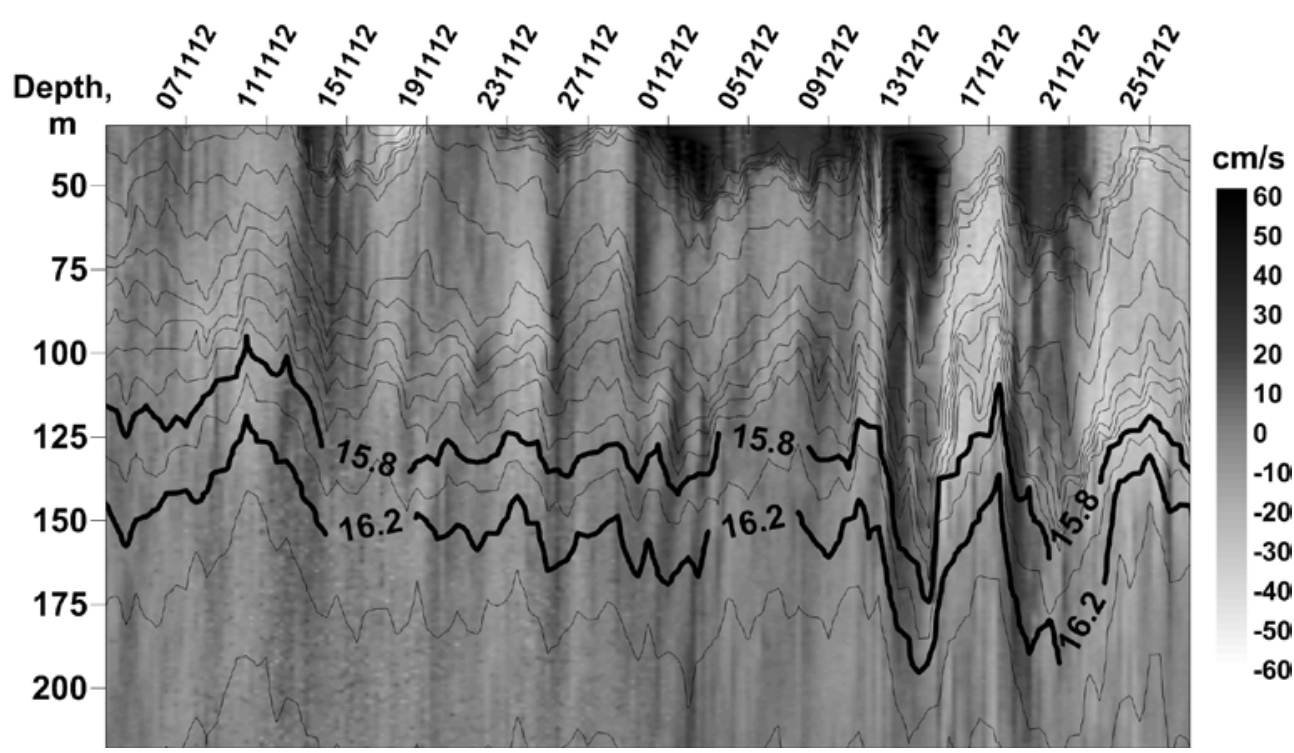

Fig. 1. Time series of vertical distributions of the longshore current velocity and potential density $\left(\sigma_{\theta}\right)$. Thin black lines are potential density isolines, isopycn of 15.8 density units is the lower boundary of the oxygen-containing layer, isopycn of 16.2 is the upper boundary of hydrogen sulphide contaminated zone; the current velocity is grayscale, its positive values directed northwest and the negative ones to southeast.

A distinctive feature of the temporal variability of current velocity and potential density fields (Fig. 1) is the presence of intense oscillations of the position of permanent pycno-halocline (14.4 - 16.2 density units) with a period of $5-15$ days. These oscillations cause the short-period changes of the oxygen-containing layer thickness from 20 to $40 \mathrm{~m}$ (see the position of the $\sigma_{\theta}=15.8$ isopycn), which can amount up to one third of its total thickness. Usage of the Aqualog autonomous profiler provides the most demonstrative image of these oscillations, proving their nonlinearity (narrow valleys and wide peaks). Their presence makes it difficult to obtain reliable estimation of the oxygen-containing zone thickness through the data of sporadic observations, since one should take into account a possible measurement error caused by these oscillations. The same applies to the estimation 
of the hydrogen sulphide upper boundary position, usually associated with the isopycn of 16.2 density units.

As mentioned above, the reason for the oscillations of isopycnic surfaces is the longshore current velocity variation due to the meandering of the Rim Current jet and the formation of mesoscale eddies (Fig. 2). When the Rim Current jet in cyclonic meander is pressed against the continental slope, the velocity of northwestern longshore current increases, the sea level in the coastal zone rises up and the isopycns, due to the geostrophic adjustment, go down. When the Rim Current jet in anticyclonic meander (eddy) moves away from the continental slope, the sea level decreases, and the isopycns close to the coast go up.
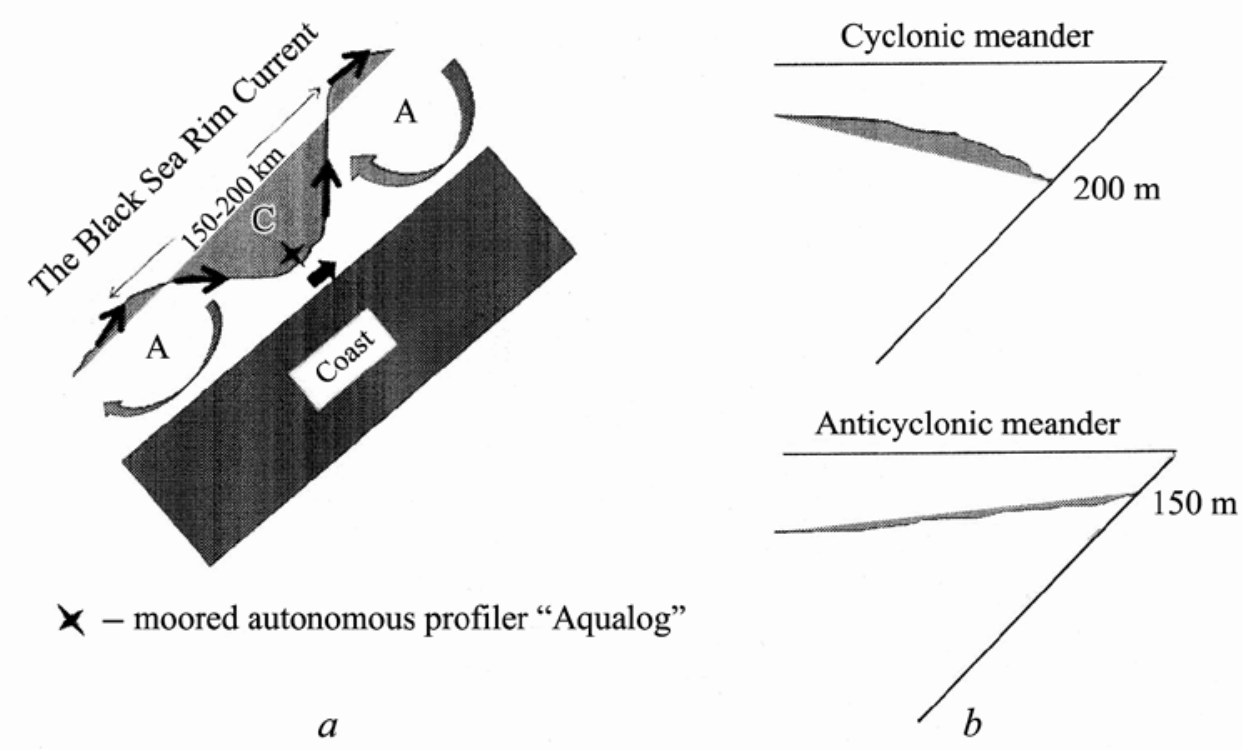

Fig 2. The Rim Current meandering jet - $a$ (black arrows on a gray background show the current core; A and concave gray arrow is the Rim Current anticyclonic meander, C - the cyclonic meander; short black arrow is the velocity of meander system shift towards the Rim Current) and the slope of isopycnic surface of 16.2, corresponding to the hydrogen sulphide upper boundary position in the cyclonic and anticyclonic meanders $-b$.

The described above longshore current velocity fluctuations near the shelf edge create environmental conditions for the realization of various dynamic modes of the shelf waters and formation of coastal sub-mesoscale eddy structures $[4,16$, $22,23]$. The diameter of these eddies, both cyclonic and anticyclonic, is comparable to the width of the shelf $(6-10 \mathrm{~km}$ in Gelendzhik area of the Black Sea). The absolute value of their angular rotation velocity exceeds the Coriolis parameter (absolute value of the Rossbi number $|\mathrm{Ro}|>1$ ), and their radius is less than the baroclinic Rossby deformation radius on the shelf. Presumably, these eddies have a significant effect on the ecology of shelf waters, affecting their ventilation, cross-shelf and vertical exchange, as well as kinetic energy dissipation of mesoscale and large-scale currents.

In 2007 - 2013 during summer-autumn season, 21 surveys measuring velocity field were carried out using the $A D C P$ in a streamline gondola towed behind the 
research vessel in the Gelendzhik study site. The sub-mesoscale eddies (Fig. 3) (15 cyclones and 16 anticyclones) were observed in 16 of 21 surveys. Vortices were mostly observed only in the upper quasi-homogeneous layer (UQL), and in the thermocline they attenuated. The typical eddy diameter, eccentricity and the Rossby number were the following: $D=2-4 \mathrm{~km}, \varepsilon=0.75$, Ro $=1.4$ for cyclones; $D=3-6 \mathrm{~km}, \varepsilon=0.80$, Ro $=0.8$ for anticyclones.

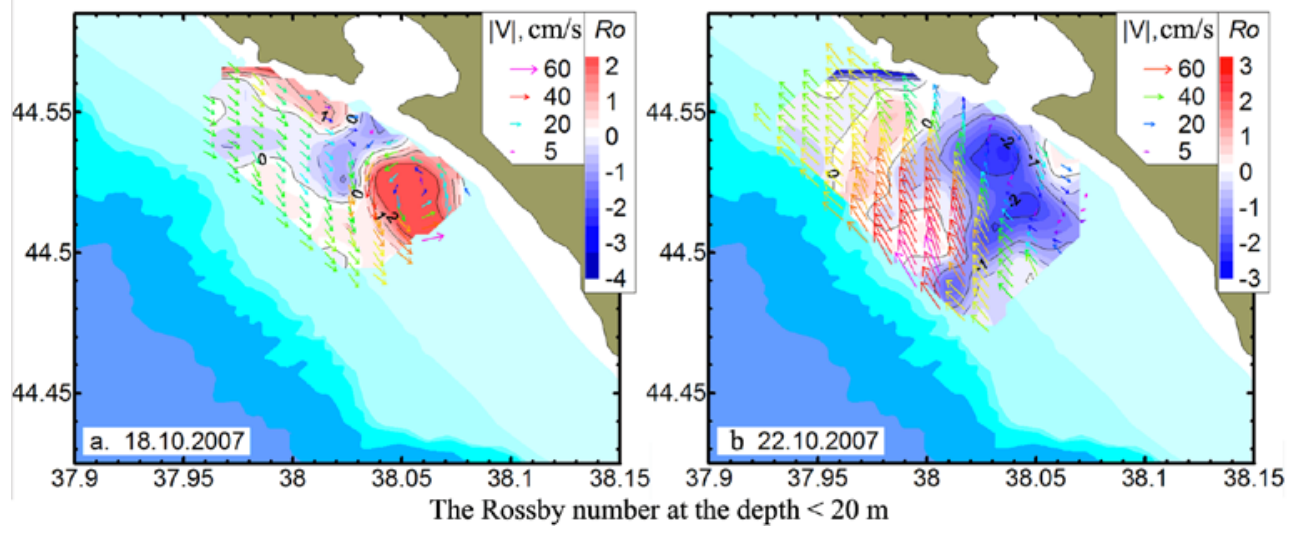

Fig. 3. Sub-mesoscale shelf eddies according to the towed $A D C P$ data obtained in the Gelendzhik study site (arrows are velocity vectors, averaged over the $20 \mathrm{~m}$ UQL thickness; the Rossby number values are colored, Ro $=\omega / f$, where $\omega$ is horizontal current velocity field vorticity, $f$ is the Coriolis parameter; cyclonic eddy area, where Ro $>1$, is marked red; blue area corresponds to the anticyclonic eddy, where Ro $<-1$ )

The characteristic orbital velocity of eddies is $20-50 \mathrm{~cm} / \mathrm{s}$. The maximum recorded eddy existence is 4 days (anticyclone).

The performed in situ research, laboratory and numerical experiments allow us to suggest the following formation scenario of the North Caucasian shelf waters dynamics, depending on the environmental conditions created by the meandering Rim Current.

When the Rim Current is pressed against the continental slope (cyclonic meander), there is a fast $(|V|>40 \mathrm{~cm} / \mathrm{s})$ current of the northwestern direction developing near the shore in the areas of capes and salient coastlines. Beyond the capes the current separates from the coast, forming post-obstacle anticyclonic submesoscale eddies. The initial eddy diameter in transverse direction to the coast is approximately equal to the size of the salient part of the cape. It can be twice as large in alongshore direction.

The eddies do not break away from the obstacle under accelerating or stationary longshore current. In time they may increase in diameter or remain invariable. Behind the rear part of the eddy and down its current the water dynamics is weak, so the ventilation of coastal zone of the sea via water exchange with the deep part is insignificant. It can be said that the cape and the attached eddy shield the post-obstacle area from the longshore current, and the current velocity is rather small there (dead zone).

After some time, usually not exceeding two days, the longshore current near the cape begins to weaken (the cyclonic meander ceases), forming the conditions PHYSICAL OCEANOGRAPHY NO. 3 (2016) 
for occasional separation of eddies from the cape and generation of new ones. Thus, 2-3 sub-mesoscale anticyclones can be formed, which move after each other down the current, in the north-west direction (Fig. 4).
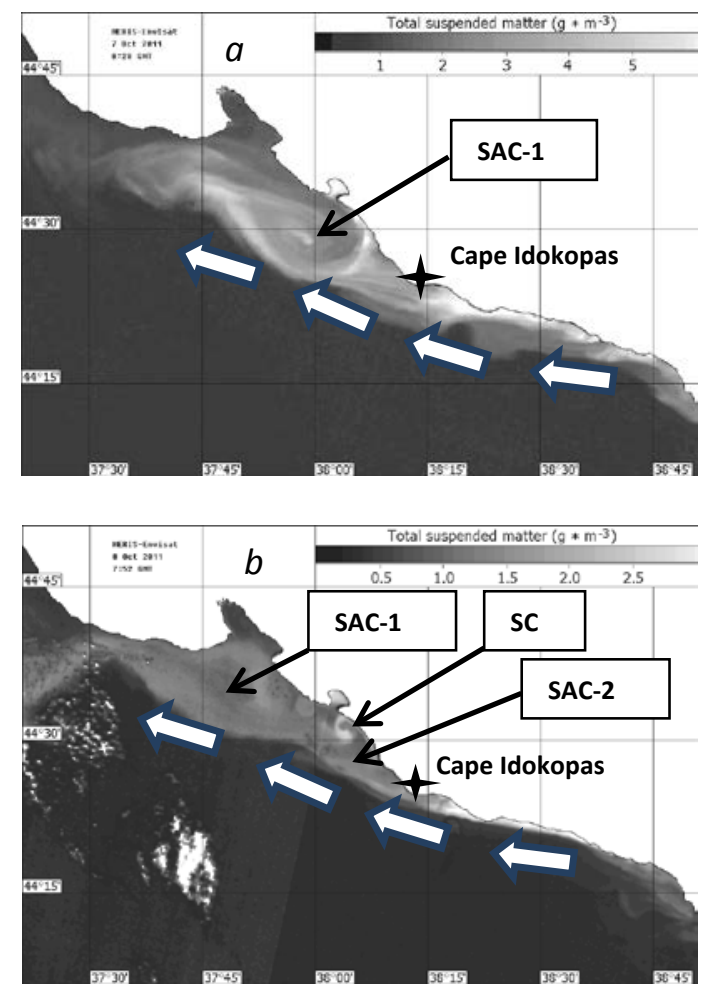

Fig. 4. The Rim Current separation from Cape Idokopas and formation of sub-mesoscale eddies in total suspended matter concentration field in two successive MERIS scanner images of Envisat satellite: $a$ - SAC-1 is the sub-mesoscale eddy separated from Cape Idokopas on 07.10.2011; $b$ SAC-1 and SAC-2 are the sub-mesoscale anticyclones, SC is the sub-mesoscale cyclone on 08.10.2011

These eddies have the diameter of $5-10 \mathrm{~km}$ and the orbital speed of $20-50$ $\mathrm{cm} / \mathrm{s}$. Small cyclones with $1-2 \mathrm{~km}$ diameter appear at the periphery of these anticyclones, in the area of cyclonic velocity shear. As they spread, sub-mesoscale anticyclones gradually attenuate and disintegrate. Sometimes, under the continuing energy and vorticity replenishment from the Rim Current, they grow in size and turn into mesoscale eddies with diameters greater than $20 \mathrm{~km}$. On average, time of their existence does not exceed several days. Sub-mesoscale anticyclones concentrate pollution over their periphery and provide its rapid transport from near the coast to the outer continental shelf and farther. Consequently, they play an important role in ventilation of the shelf waters, especially in the post-obstacle areas with a concave shoreline, where water dynamics is weakened in comparison with the shelf areas with a convex shoreline. 


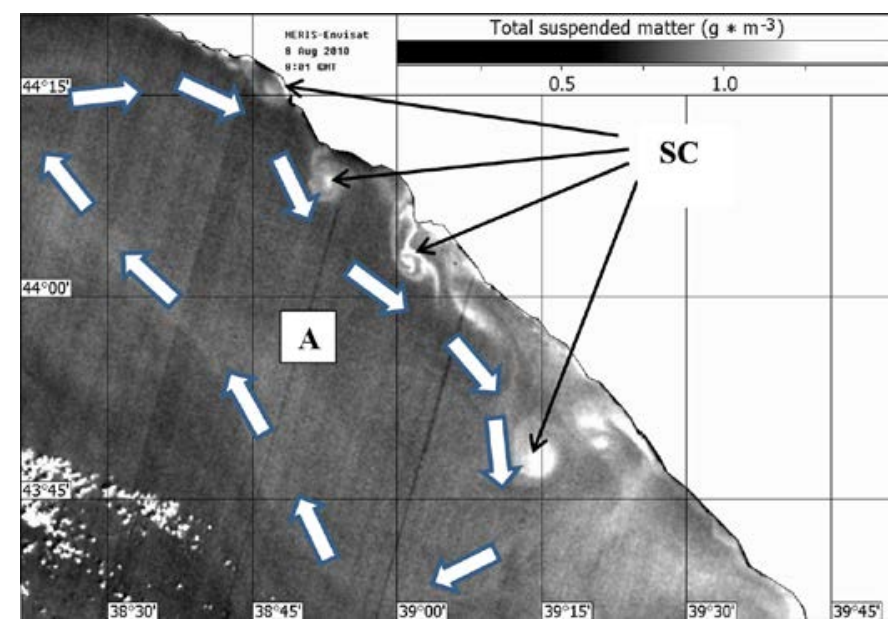

Fig. 5. Sub-mesoscale cyclones (SC) on the periphery of the mesoscale anticyclone (A) in the northeastern Black Sea (MERIS scanner image of Envisat satellite, August, 8, 2010, the suspended matter concentration field)

Once a cyclonic meander has passed and an anticyclonic meander or a mesoscale eddy took its place, general direction of the flow beyond the shelf edge changes the sign, and the longshore transport direction becomes southeastern. If the southeastern current is strong enough $(|\mathrm{V}|>30 \mathrm{~cm} / \mathrm{s})$ and is pressed against the shelf edge, a zone with a significant horizontal velocity shear with a cyclonic vorticity is formed between the shelf edge and the shore. In that case, in the area of the current shear the chains of intense sub-mesoscale cyclonic eddies are sometimes formed. These eddies are clearly visible on satellite images in the concentration field of total suspended matter (Fig. 5), because of the uprise of phytoplankton-rich cold waters from the upper part of the thermocline to the surface due to eddy-generated local upwelling [16]. As a result of the water rapid orbital rotation, the sea level in the centers of the sub-mesoscale cyclones can be a few centimeters lower than on the periphery. With the sub-mesoscale cyclone destruction, the upwelling in its core is replaced by downwelling. As a result, the suspended matter goes down to the UQL bottom boundary, and the eddies are no longer visible on satellite images in the fields of temperature and suspended matter concentration.

It should be noted that in the presence of southeastern longshore current the fact of eddies generation behind the capes is not as evident as in the case of northwestern current, and even if the post-obstacle cyclonic eddies are formed, they do not get separated from the capes and do not form the eddy chains. In turn, when the northwestern current is present in the velocity shear zone between the current core and the shore, the chains of anticyclonic eddies that form due to the current shear instability are normally not observed. These empirical data of observations are confirmed by the laboratory experiments [24, 25]. Such an asymmetry in the conditions of cyclonic and anticyclonic sub-mesoscale eddy formation is a result of the Earth's rotation and is not observed in the non-rotating fluid. 
Summary and conclusions. Conceptual scheme of the sub-mesoscale cyclonic and anticyclonic eddy formation on the narrow North Caucasian shelf between Capes Idokopas and Utrish is shown in Fig. 6.

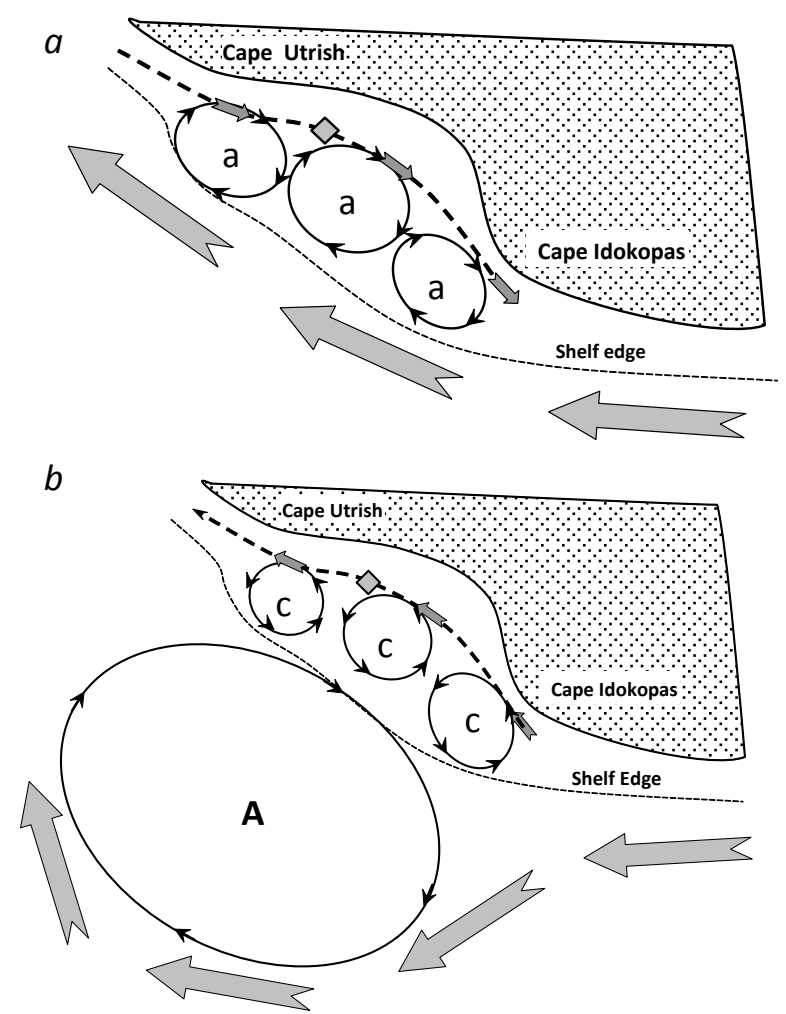

Fig. 6. Scheme of the sub-mesoscale cyclonic and anticyclonic eddy formation on the narrow North Caucasian shelf: a - in the presence of the Rim Current pressed against the continental slope (the northwestern current near the shelf edge), when anticyclonic eddies are formed past the capes due to the separation of the current from the coast; $b$ - in the presence of the anticyclonic meander, or the Rim Current eddy (the southeastern current near the shelf edge), when the cyclonic eddies are formed due to the shear instability

Considering that the characteristic period of oscillations of the general direction of the longshore current, caused by the Rim Current meandering, is about 10 days, it can be assumed that mainly anticyclones should be observed on the shelf during one half of the period (cyclonic meander, or the Rim Current is pressed against shelf edge) (Fig. 6, a) and cyclones during the other half (anticyclonic meander, or mesoscale eddy) (Fig. 6, b). Unfortunately, continuous and long-term observation data, which would allow modeling the velocity field on the sub-satellite study site of IO RAS, Gelendzhik, were not obtained so far. The provided statistics of observation of sub-mesoscale eddies on the shelf through separate ADCP-surveys of the current velocity field during the warmer part of year have shown that the number of cyclones and anticyclones is approximately the same. The shelf eddies on the IO RAS study site were observed in approximately $75 \%$ of the surveys in the warm season. However, it remains unclear what is happening on the shelf in the cold season. It can be assumed that the increased wind pumping in winter leads to the Rim Current intensification and closer 20 
adjacency to the continental slope, resulting in the formation of mostly submesoscale anticyclones in the shelf zone.

In summary, it should be noted that the available data of observations do not contradict the above-described scheme of the formation of dynamics structure of shelf waters. However, it should be considered quite rough and in need of further refinement.

Acknowledgements. The work was supported by the All-Russian public organization "Russian Geographical Society", Grant No.13-05-41450, Contract No. 10/2013/RGS-RFBR.

\section{REFERENCES}

1. Zatsepin, A.G., Kremenetskiy, V.V. \& Poyarkov, S.G. [et al.], 2002, "Vliyanie polya vetra na dinamiku vod Chernogo morya [The wind field effect on the dynamics of the Black Sea waters]”, Kompleksnye issledovaniya severo-vostochnoy chasti Chernogo morya, pp. 91-105 (in Russian).

2. Zatsepin, A.G., Kremenetskiy, V.V. \& Stanichnyy, S.V. [et al.], 2010, "Basseynovaya tsirkulyatsiya i mezomasshtabnaya dinamika Chernogo morya pod vetrovym vozdeystviem [Basin circulation and mesoscale dynamics of the Black Sea under the wind effect]", Sovremennye problemy dinamiki okeana i atmosfery, Sb. statey, posvyashchennyy 100-letiyu so dnya rozhdeniya P.S. Lineykina, pod red. A.V. Frolova, Yu.D. Resnyanskogo, Moscow, Triada LTD, pp. 345-368 (in Russian).

3. Moskalenko, L.V., 1975, "Raschet statsionarnykh vetrovykh techeniy $v$ Chernom more [Calculation of stationary wind currents in the Black Sea]", Okeanologiya, vol. 15, iss. 2, pp. 245-250 (in Russian).

4. Ovchinnikov, I.M., Titov, V.B., 1990, “Antitsiklonicheskaya zavikhrennost' techeniy $v$ pribrezhnoy zone Chernogo morya [Anticyclonic vorticity in the coastal zone of the Black Sea], Dokl. AN SSSR, vol. 314, no. 5, pp. 1236-1239 (in Russian).

5. Korotaev, G.K., Oguz, T. \& Nikiforov, A. [et al.], 2003, "Seasonal, interannual, and mesoscale variability of the Black Sea upper layer circulation derived from altimeter data", J. Geophys. Res., vol. 108, no. C4, p. 3122.

6. Kubryakov, A.A., Stanichny, S.V., 2015, "Seasonal and interannual variability of the Black Sea eddies and its dependence on characteristics of the large-scale circulation”, Deep-Sea Res. Part I: Oceanogr. Res. Pap., vol. 97, pp. 80-91.

7. Stanev, E.V., 1990, “On the mechanisms of the Black Sea circulation”, Earth-Sci. Rev., vol. 28, pp. 285-319.

8. Zatsepin, A.G., Ginzburg, A.I. \& Kostianoy, A.G. [et al.], 2002, "Variability of water dynamics in the NE Black Sea and its effect on water exchange between near-shore and offshore parts of the basin”, Oceanology, vol. 42, Suppl. 1, pp. S1-S15.

9. Zatsepin, A.G., Denisov, E.S. \& Emelyanov, S.V. [et al.], 2005, "Effect of bottom slope and wind on the near-shore current in a rotating stratified fluid: laboratory modeling for the Black Sea”, Oceanology, vol. 45, Suppl. 1, pp. S13-S26.

10. Blatov, A.S., Bulgakov, N.P. \& Ivanov, V.A. [et al.], 1984, “Izmenchivost' gidrofizicheskikh poley $v$ Chernom more [The variability of hydrophysical fields in the Black Sea]", Leningrad, Gidrometeoizdat, 240 p. (in Russian).

11. Bogatko, O.N., Boguslavskiy, S.G. \& Belyakov, Yu.M. [et al.], 1979, "Poverkhnostnye techeniya Chernogo morya [Surface currents of the Black Sea]", Kompleksnye issledovaniya Chernogo morya, pp. 25-33 (in Russian).

12. Ginzburg, A.I., 1994, "Protsessy gorizontal'nogo obmena $v$ pripoverkhnostnom sloe Chernogo morya [Horizontal exchange processes in the Black Sea surface layer]", Issledovanie Zemli iz kosmosa, no. 2. pp. 75-83 (in Russian). 
13. Zatsepin, A.G., Ginzburg, A.I. \& Kostianoy, A.G. [et al.], 2003, Observations of Black Sea mesoscale eddies and associated horizontal mixing”, J. Geophys. Res., vol. 108, no. C8, doi: 10.1029/2002JC001390, pp. 2-1 - 2-27.

14. Zatsepin, A.G., Ostrovskiy, A.G. \& Kremenetskiy, V.V. [et al.], 2014, "Podsputnikovyy poligon dlya izucheniya gidrofizicheskikh protsessov $v$ shel'fovo-sklonovoy zone Chernogo morya [Subsettelite polygon for studying hydrophysical processes in the Black Sea shelfslope zone]”, Izv. RAN. Fizika atmosfery i okeana, no. 1, pp. 16-29 (in Russian).

15. Zhurbas, V.M., Zatsepin, A.G. \& Grigor'eva, Yu.V. [et al.], 2003, “Tsirkulyatsiya vod i kharakteristiki raznomasshtabnykh techeniy $v$ verkhnem sloe Chernogo morya po drifternym dannym [Water circulation and the characteristics of large-scale currents in the upper layer of the Black Sea according to the drift data]", Okeanologiya, vol. 43, no. 6, pp. 1-15 (in Russian).

16. Zatsepin, A.G., Ostrovskiy, A.G. \& Kremenetskiy, V.V. [et al.], 2013, "O prirode korotkoperiodnykh kolebaniy osnovnogo chernomorskogo piknoklina, submezomasshtabnykh vikhryakh i reaktsii morskoy sredy na katastroficheskiy liven' $2012 \mathrm{~g}$. [On the nature of shortperiod fluctuations of the Black Sea main pycnocline sub-mesoscale eddies and the reaction of the marine environment on the disastrous rainfall in 2012]”, Izv. Ran. Fizika atmosfery $i$ okeana, no. 6, pp. 717-732 (in Russian).

17. Titov, V.B., 1980, “O kharaktere tsirkulyatsii $i$ vertikal'noy strukture techeniy $v$ vostochnoy chasti Chernogo morya [On the circulation nature and the vertical structure of the currents in the eastern part of the Black Sea]”, Okeanologiya, vol. 20, no. 3, pp. 425-431 (in Russian).

18. Titov, V.B., 1991, "Statisticheskie kharakteristiki i izmenchivost' techeniy na zapadnom shel'fe Chernogo morya [Statistical characteristics and variability of currents on the western shelf of the Black Sea]”, Morskoy gidrofizicheskiy zhurnal, no. 2, pp. 41-47 (in Russian).

19. Titov, V.B., Savin, M.T., 1997, “Izmenchivost' pridonnykh techeniy na severo-vostochnom shel'fe Chernogo morya [The variability of bottom currents in the Black Sea north-eastern shelf]”, Okeanologiya, vol. 37, no. 1, pp. 50-55 (in Russian).

20. Titov, V.B., 2002, "Kharakteristiki osnovnogo chernomorskogo techeniya i pribrezhnykh antitsiklonicheskikh vikhrey $v$ rossiyskom sektore Chernogo morya [Features the Black Sea Rim Current and coastal anticyclonic eddies in the Russian Black Sea sector]”, Okeanologiya, vol. 42, no. 5, pp. 668-676 (in Russian).

21. Ostrovskiy, A.G., Zatsepin, A.G. \& Solov'ev, V.A. [et al.], 2013, “Avtonomnyy mobil'nyy apparatno-programmnyy kompleks vertikal'nogo zondirovaniya morskoy sredy na zayakorennoy buykovoy stantsii [Autonomous mobile hardware-software complex of vertical probing of the marine environment on a moored buoy station]”, Okeanologiya, vol. 53, no. 2, pp. 259-268 (in Russian).

22. Zatsepin, A.G., Kondrashov, A.A. \& Korzh, A.O. [et al.], 2011, "Submezomasshtabnye vikhri na kavkazskom shel'fe Chernogo morya i porozhdayushchie ikh mekhanizmy [Sub-mesoscale eddies in the Caucasian Black Sea shelf and their generating mechanisms]", Okeanologiya, vol. 51, no. 4, pp. 592-605 (in Russian).

23. Zatsepin, A.G., Piotukh, V.B. \& Korzh, A.O. [et al.], 2012, "Izmenchivost' polya techeniy $v$ pribrezhnoy zone Chernogo morya po izmereniyam donnoy stantsii ADCP [The variability of current fields in the Black Sea coastal zone from the ADCP bottom station measurements]", Okeanologiya, vol. 52, no. 5, pp. 629-642 (in Russian).

24. Elkin, D.N., Zatsepin, A.G., 2013, “Laboratornoe issledovanie mekhanizma periodicheskogo vikhreobrazovaniya za mysami $v$ pribrezhnoy zone morya [In situ research of the eddy formation mechanism behind the capes in the coastal area]”, Okeanologiya, vol. 53, no. 2, pp. 259-268 (in Russian).

25. Elkin, D.N., Zatsepin, A.G., 2014, “Laboratornoe issledovanie mekhanizma sdvigovoy neustoychivosti morskogo vdol'beregovogo techeniya [In situ research of the mechanism of marine longshore current shear instability]”, Okeanologiya, vol. 54, no. 5, pp. 614-621 (in Russian). 